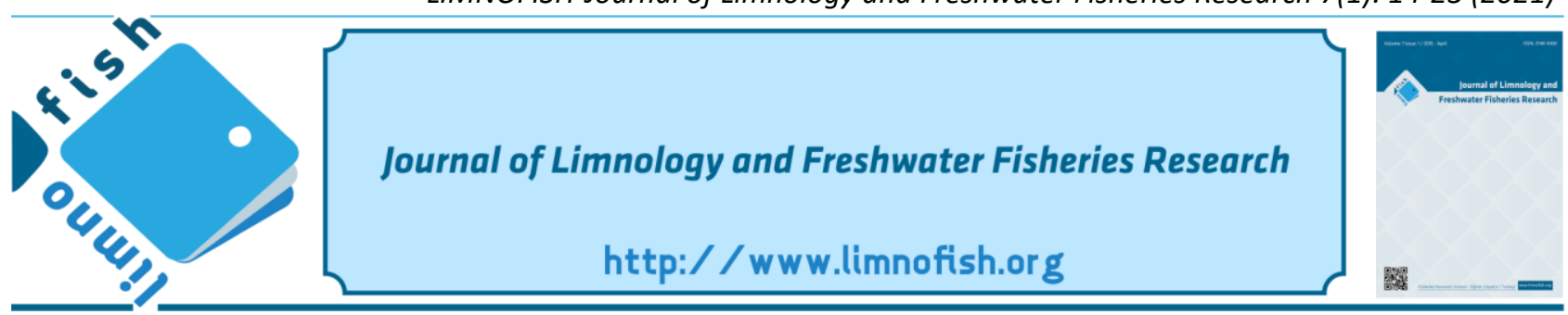

\title{
The Comparative Gut Content Analysis of Some Chironomidae Larvae Living in the Freshwaters at Northern Thrace Region of Turkey
}

\author{
Gazel Burcu AYDIN $^{1 *}$ (D), Burak ÖTERLER ${ }^{1}$ (D), Belgin ÇAMUR ELİPEK ${ }^{1}{ }^{(D)}$, Hüseyin GÜHER ${ }^{1}$ \\ ${ }^{1}$ Trakya University, Faculty of Science, Department of Biology, 22100 Edirne-Turkey
}

\section{A B STR ACT}

The roles of larval chironomids in the food chain of both the lotic and the lentic ecosystems are very important. On the one hand, chironomid larvae feeding on algae, diatoms, rotting organic matter, plant, and animal residues also play an important role in these systems as a source of food for other carnivores and omnivorous organisms. In this study, the gut contents of Cryptochironomus defectus (Kieffer, 1913), Cladotanytarsus mancus (Walker, 1856), Polypedilum scalaenum (Schrank, 1803), Tanypus kraatzi (Kieffer, 1912) collected from the freshwater ecosystems located in the northern parts of the Thrace region of Turkey were analyzed to compare their feeding habits. As a result of the analysis, it was determined that while plant fragments were dominant in $C$. defectus species in the gut content (44.3\%), algae were dominant for C. mancus (44.7\%), P. scalaenum (63.5\%), T. kraatzi (65\%). According to the results of the Shannon-Wiener $\left(\mathrm{H}^{\prime}\right)$ index species, diversity of the $P$. scalaenum was found to be the highest among the larvae $\left(H^{\prime}=1.345\right)$. Also, according to the Bray-Curtis similarity index, the most similar types of gut contents were P. scalaenum and C. defectus (38\%). This low rate indicated that the species have different food preferences.

\section{ARTICLE INFO}

RESEARCH ARTICLE

Received : 23.05.2020

Revised : :16.09.2020

Accepted :08.10.2020

Published :29.04.2021

DOI:10.17216/LimnoFish.741780

* CORRESPONDING AUTHOR

gburcuaydin@trakya.edu.tr

Phone : +902842352825

Keywords: Chironomidae, gut content, food chain, Turkish Thrace

\section{Türkiye'nin Kuzey Trakya Bölgesi'ndeki Tatlı Sularda Yaşayan Bazı Chironomidae Larvalarının} Karşılaştırmalı Mide İçerik Analizi

Öz: Gerek lotik gerekse lentik ekosistemlerin besin zincirinde larval chironomidlerin rolü oldukça büyüktür. Ayrıca, algler, diyatomlar, çürüyen organik madde, bitki ve hayvan kalıntıları ile beslenen chironomid larvaları, bu sistemlerde diğer karnivor ve omnivor organizmalar için bir besin kaynağı olarak da önemli bir rol oynamaktadır. Bu çalışmada, Trakya Bölgesi'nin kuzey bölgelerinde bulunan tatlı su ekosistemlerinden toplanan Cryptochironomus defectus (Kieffer, 1913), Cladotanytarsus mancus (Walker, 1856), Polypedilum scalaenum (Schrank, 1803), Tanypus kraatzi (Kieffer, 1912) türlerinin mide içerikleri, bu türlerin beslenme alışkanlıklarını karşılaştırmak için analiz edildi. Analiz sonucunda C. defectus'un mide içeriğinde (\%44,3) bitki parçalarının baskın olduğu, C. mancus (\%44,7), P. scalaenum (\%63,5), T kraatzi (\%65) için alglerin baskın olduğu belirlendi. Shannon-Wiener $\left(\mathrm{H}^{\prime}\right)$ indeksi sonuçlarına göre, $P$. scalaenum 'un mide içeriğinin çeşitliliğinin larvalar arasında en yüksek olduğu bulundu $\left(\mathrm{H}^{\prime}=1,345\right)$. Ayrıca, Bray-Curtis benzerlik endeksine göre, mide içeriği en benzer $P$. scalaenum ve $C$. defectus olduğu saptand $(\% 38)$. Bu düşük oran, türlerin farklı besin tercihlerine sahip olduğunu gösterdi.

Anahtar kelimeler: Chironomidae, mide içeriği, besin zinciri, Türkiye Trakya'sı

\section{How to Cite}

Aydın GB, Öterler B, Çamur Elipek B, Güher H. 2021. The Comparative Gut Content Analysis of Some Chironomidae Larvae Living in the Freshwaters at Northern Thrace Region of Turkey. LimnoFish. 7(1): 14-23. doi: 10.17216/LimnoFish.741780

\section{Introduction}

Gut content analysis of chironomid larvae provides significant data on their ecological and biological structure, importance in the food chain, habitat use, and modes of feed (Armitage et al. 1995; Manko 2016). In an aquatic ecosystem, chironomid larvae have an important place since they are the most abundant organisms and have an important role in the food chain by being the food of fish, other aquatic invertebrates and by feeding on algae, detritus, associated microorganisms, fungi, woody debris, macrophytes, other aquatic invertebrates (Armitage et al. 1995; Epler 2001; Butakka et al. 2016). Therefore, it can be said that chironomid larvae are an important connection point of the food web in an aquatic ecosystem by being a bridge between 
producers and consumers (Silva et al. 2008). The gut content studies of chironomid larvae provide important insights into the modes of feeding and according to based on larval feeding modes chironomids can be grouped into collector-gatherers, collector-filterers, scrapers, shredders, engulfers, and piercers (Armitage et al. 1995). But it is important to know that most chironomid larvae are not limited to a single mode of feeding and it is based on larval size, food size and quality, sediment composition (Armitage et al. 1995; Kornijo'w et al. 2019). The other factor on the chironomids feeding is swallowing food non-selectively and selectively in accordance with food availability, type, and size (Armatige et al. 1995). Studies of chironomid feeding show that the diet of chironomids constitutes of detritus and associated microorganisms, macrophytes, invertebrates, and especially algae (Baker and Mclachlan 1979; Armitage et al. 1995; Sanseverino and Nessimian 2008; Butakka et al. 2016; Öterler et al. 2018; Kornijo'w et al. 2019).

In this study, it was aimed to analyze the gut contents of the four species (Cryptochironomus defectus, Cladotanytarsus mancus, Polypedilum scalaenum, and Tanypus kraatzi) collected from freshwater resources at the Northern Thrace Region of Turkey and make comparisons about the feeding modes and feeding similarities of the species.

\section{Materials and Methods \\ Sampling}

The Thrace Region is the European Part of Turkey and was surrounded by Bulgaria, Greece, and the Black Sea (Figure 1). The material of the study was collected at ten different freshwater resources located in the northern parts of the Thrace region between June 2012 and August 2012. The locality names, habitat features, and coordinates were given in Table 1 . The sediment samples were taken by a hand mud scoop net and the obtained material was washed through mesh nets then preserved in $250 \mathrm{cc}$ plastic bottles containing $70 \%$ ethanol. In the laboratory, chironomid larvae were selected from the sediment using a binocular stereomicroscope.

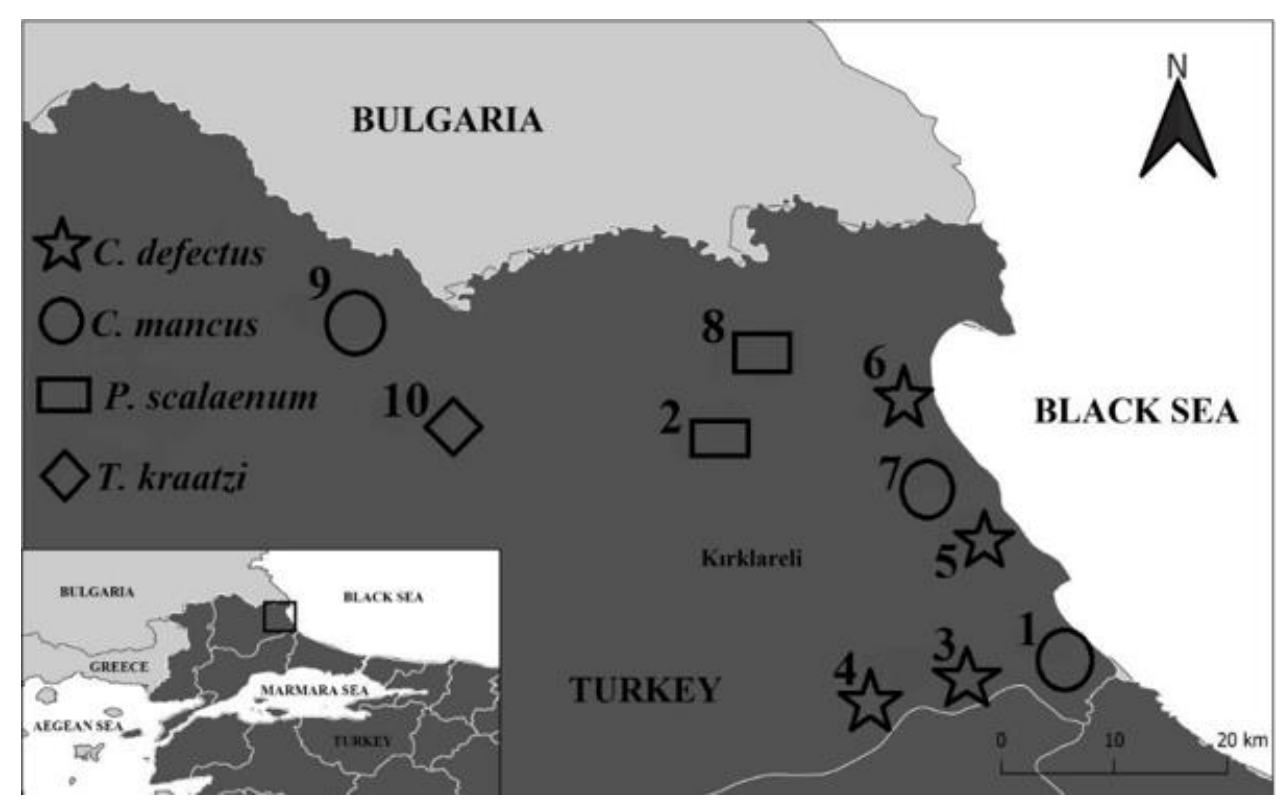

Figure 1. Locations of sampling sites of the chironomid larvae.

\section{Analyses}

For the larval identification, Saether (1980), Fittkau and Roback (1983), Pinder and Reiss (1983), Epler (2001), and Vallenduuk and Morozova (2005) were followed. The fourth instar stage of the samples was selected among the material for the gut content analysis. Ten specimens for each species were used to analyze the gut contents. Each chosen specimen was placed into petri dishes containing $1 \mathrm{ml}$ of $70 \%$ ethanol and dissected to reveal the gut contents by using a needle under a binocular stereo-microscope. The diffused material in the petri dish was infused into a Sedgewick-Rafter count chamber with a $1 \mathrm{ml}$ volume. All of the organic and inorganic materials in the gut contents were counted. Algal biovolume was estimated from the abundancedata and measurements of specific cell volumes by approximating geometric shapes of the cells (Hillebrand et al. 1999; Sun and Liu 2003). Identifications were performed at 1000x magnification under immersion oil, and identification of the taxa was based on the literature (Huber-Pestalozzi 1982; John et al. 2002; Krammer and Lange-Bertalot 1986-2004; Round et al. 1990; 
Komárek and Anagnostidis 2005; Hindak 2008; Kristiansen and Preisig 2011). All of the determined species were confirmed using AlgaeBase, an electronic database of algae information hosted by the National University of Ireland (Guiry and Guiry 2020).

Table 1. The features of the locations where the larvae were collected.

\begin{tabular}{cccc}
\hline Locations & Locality Name & Habitat & Coordinates \\
\hline Loc. 1 & Kazandere Brook & Stream & $41^{\circ} 37^{\prime} 57^{\prime \prime} \mathrm{N}, 28^{\circ} 05^{\prime} 12^{\prime \prime} \mathrm{E}$ \\
Loc. & Kömürköy Brook & Stream & $41^{\circ} 40^{\prime} 18^{\prime \prime} \mathrm{N}, 26^{\circ} 33^{\prime} 40^{\prime \prime} \mathrm{E}$ \\
Loc. 3 & Kazandere Dam Lake & Lake & $41^{\circ} 37^{\prime} 49^{\prime \prime} \mathrm{N}, 28^{\circ} 05^{\prime} 14^{\prime \prime} \mathrm{E}$ \\
Loc. 4 & Pabuçdere/Kiyıköy & Stream & $41^{\circ} 39^{\prime} 55^{\prime \prime} \mathrm{N}, 27^{\circ} 57^{\prime} 30^{\prime \prime} \mathrm{E}$ \\
Loc.5 & Pabuçdere/Hamidiye & Stream & $41^{\circ} 39^{\prime} 55^{\prime \prime} \mathrm{N}, 27^{\circ} 57^{\prime} 30^{\prime \prime} \mathrm{E}$ \\
Loc.6 & Saka Brook & Stream & $41^{\circ} 48^{\prime} 42^{\prime \prime} \mathrm{N}, 27^{\circ} 57^{\prime} 02^{\prime \prime} \mathrm{E}$ \\
Loc. & Saka Lake & Lake & $41^{\circ} 48^{\prime} 00^{\prime \prime} \mathrm{N}, 27^{\circ} 59^{\prime} 40^{\prime \prime} \mathrm{E}$ \\
Loc.8 & Pedina Lake & Lake & $41^{\circ} 50^{\prime} 01^{\prime \prime} \mathrm{N}, 27^{\circ} 56^{\prime} 05^{\prime \prime} \mathrm{E}$ \\
Loc.9 & Dereköy Brook & Stream & $41^{\circ} 55^{\prime} 48^{\prime \prime} \mathrm{N}, 27^{\circ} 22^{\prime} 14^{\prime \prime} \mathrm{E}$ \\
Loc.10 & Armağan Village & Pond & $41^{\circ} 52^{\prime} 31^{\prime \prime} \mathrm{N}, 27^{\circ} 25^{\prime} 43^{\prime \prime} \mathrm{E}$ \\
\hline
\end{tabular}

\section{Data Analysis}

Shannon-Wiener index was used for the evaluation of the species diversity of the larval gut contents. The Bray-Curtis and Correspondence index analyses were used to determine the similarities of the gut contents of the species. Analyses were carried out with the XLSTAT-ADA statistical package program (Addinsoft 2015) and Graphpad PRISM software, trial version (Intuitive Software for Science, San Diego, CA).

\section{Results}

Four species were determined in the studied area (Cryptochironomus defectus, Cladotanytarsus mancus, Polypedilum scalaenum, Tanypus kraatzi).
While a total of 81 algal species were determined in the gut contents of the larvae, it was observed that the other food fragments belonged to plants, animals, and fungi. The analyses showed that the gut contents of the larvae consisted of algae $(52.7 \%)$ followed by plant fragments $(27.8 \%)$, animal fragments (10.2\%), and fungi spores (9.3\%) (Figure 2). These proportional data belonged to only approximately $50-70 \%$ of the alimentary tract of larvae. Because the data in our study included gut content data other than detritus. It is known that detrital components (nonliving organic and inorganic matter, microorganisms, bacteria), constitute about $50 \%$ of the gut contents and some larvae could complete the larval stage on the detrital components (Rodina 1971).
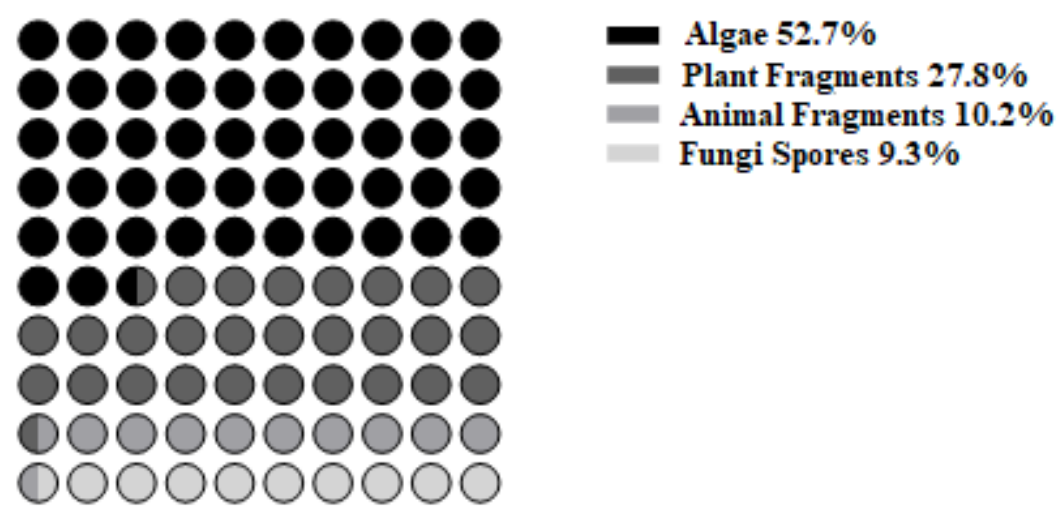

$$
\text { Total }=\% 100
$$

Figure 2. The composition of food items observed in gut contents of the chironomid larvae.

The results of the analyses showed that plant fragments were the dominant diet of the gut content of $C$. defectus (44.3\%) followed by algae (37.3\%), fungi spores (12.7\%), and animal fragments (5.7\%). Algae were the dominant diet of the gut content of
P. scalaenum $(63.5 \%)$ followed by fungi spores (19\%), plant fragments (16.5\%), and animal fragments (1\%). In the gut content of C. mancus, algae were dominant $(44.7 \%)$ and were followed by plant fragments (32\%), animal fragments (18.7\%), 
and fungi spores (4.6\%). The gut content of T. kraatzi consisted of algae $(65 \%)$, plant fragments $(18.5 \%)$, animal fragments $(15.5 \%)$, and fungi spores (1\%) (Figure 3).

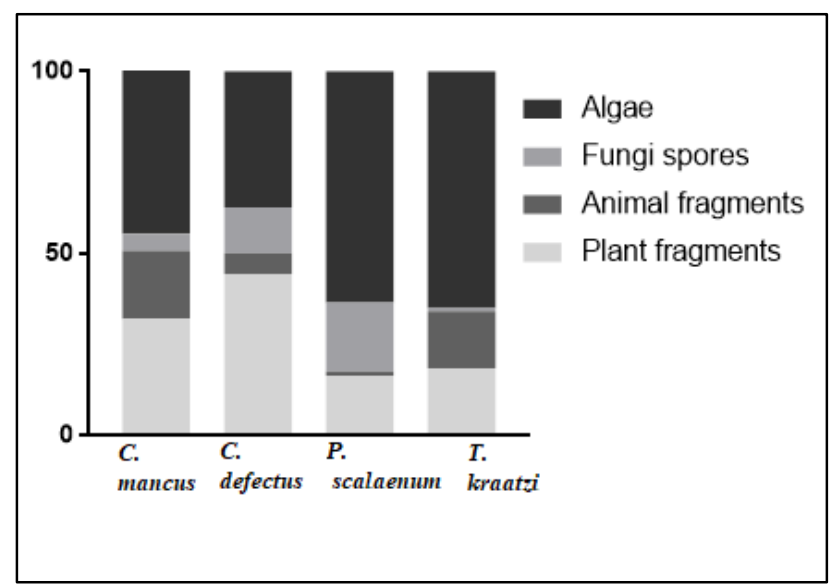

Figure 3. The gut contents of the determined chironomid larvae.

A total of 81 taxa belonging to 5 algal divisions were found in the gut contents of the four chironomid larvae (Table 2). They were
Bacillariophyta (with 57 taxa), Euglenophyta (with 1 taxon), Chlorophyta (with 9 taxa), Cyanophyta (with 7 taxa), and Charophyta (with 7 taxa). Based on the data of the algal composition of the larvae, diatoms were dominant for all species (Figure 4). However, euglenoids were found only on the gut content of T. kraatzi (Figure 4). Several gut content studies reporting benthic algae as the basic food source for chironomids showed that diatoms especially constitute most of the diet (Tarkowska-Kukuryk 2013; Butakka et al. 2016; Kornijo'w et al. 2019). Members of the subfamily Chironominae, known as non-predatory fed primarily on algae especially diatoms, and in this study the algal diet of C. defectus, C. mancus and P. scalaenum (members of subfamily Chironominae) consisted of mostly diatoms (Figure 4). However, the diatom preference is not restricted to taxa considered to be non-predators. Although subfamily Tanypodinae is known as a predator, as determined in our study members of Tanypus genus can preference diatoms as a major food source (Armitage et al. 1995; Galizzi et al. 2012).

Table 2. The composition of gut contents of chironomid larvae.

\begin{tabular}{|c|c|c|c|c|}
\hline & C. mancus & C. defectus & P. scalaenum & T. kraatzi \\
\hline \multicolumn{5}{|l|}{ Kingdom: Chromista } \\
\hline \multicolumn{5}{|l|}{ Phylum: Bacillariophyta } \\
\hline \multicolumn{5}{|l|}{ Class: Coscinodiscophyceae } \\
\hline Melosira varians C.Agardh 1827 & & + & & \\
\hline \multicolumn{5}{|l|}{ Class: Mediophyceae } \\
\hline Cyclotella meneghiniana Kützing 1844 & + & + & + & + \\
\hline Stephanodiscus hantzschii Grunow 1880 & & & + & \\
\hline \multicolumn{5}{|l|}{ Class: Bacillariophyceae } \\
\hline Lemnicola exigua Grunow 1880 & & + & & \\
\hline $\begin{array}{l}\text { Planothidium lanceolatum (Brébisson ex } \\
\text { Kützing) Lange-Bertalot } 1999\end{array}$ & + & & + & \\
\hline Achnanthes armillaris (O.F.Müller) Guiry 2019 & & & + & \\
\hline $\begin{array}{l}\text { Achnanthidium minutissimum (Kützing) } \\
\text { Czarnecki } 1994\end{array}$ & + & & + & + \\
\hline Achnanthidium sp. & & + & & \\
\hline Amphora ovalis (Kützing) Kützing 1844 & & + & & \\
\hline Caloneis sp. & & & & + \\
\hline Caloneis amphisbaena (Bory) Cleve 1894 & & & & + \\
\hline Cocconeis sp. & & & & + \\
\hline Cocconeis placentula Ehrenberg 1838 & + & + & + & \\
\hline Craticula sp. & & & + & \\
\hline $\begin{array}{l}\text { Craticula cuspidata } \\
\text { (Kutzing) D.G.Mann } 1990 \\
\end{array}$ & & & & + \\
\hline Cymbella sp. & & & + & \\
\hline Cymbella affinis Kützing; 1844 & & & + & + \\
\hline Cymbella cistula (Ehrenberg) O.Kirchner 1878 & + & & & + \\
\hline
\end{tabular}


Table 2. Continued.

\begin{tabular}{|c|c|c|c|c|}
\hline & C. mancus & C. defectus & P. scalaenum & T. kraatzi \\
\hline Cymbella excisa Kützing 1844 & + & & & \\
\hline $\begin{array}{l}\text { Brebissonia lanceolata (C.Agardh) Mahoney \& } \\
\text { Reimer, } 1986\end{array}$ & & & & + \\
\hline $\begin{array}{l}\text { Cymbopleura naviculiformis (Auerswald ex } \\
\text { Heiberg) Krammer } 2003\end{array}$ & + & + & & \\
\hline Denticula sp. & + & & & \\
\hline Denticula elegans Kützing 1844 & & + & & \\
\hline Diatoma vulgaris Bory 1824 & & & + & \\
\hline $\begin{array}{l}\text { Encyonema minutum Cholnoky) D.B.Czarnecki } \\
1994\end{array}$ & & & + & \\
\hline $\begin{array}{l}\text { Encyonema silesiacum (Bleisch) D.G.Mann in } \\
\text { Round, R.M.Crawford \& D.G.Mann } 1990\end{array}$ & + & & & \\
\hline Epithemia sp. & & + & & \\
\hline Epithemia sorex Kützing 1844 & & & & + \\
\hline Epithemia turgida Kützing 1844 & + & + & & \\
\hline Epithemia adnata (Kützing) Brébisson 1838 & + & & & \\
\hline $\begin{array}{l}\text { Fragilaria capucina (Kützing) Lange-Bertalot } \\
1980\end{array}$ & & & & + \\
\hline Ulnaria ulna (Nitzsch) Compère; 2001 & + & + & + & + \\
\hline Gomphonema sp. & & & & + \\
\hline Gomphonema acuminatum Ehrenberg 1832 & & & & + \\
\hline Gomphonema gracile Ehrenberg 1838 & + & & & \\
\hline $\begin{array}{l}\text { Gomphonema parvulum (Kützing) Kützing } \\
1849\end{array}$ & + & + & + & + \\
\hline Gomphonema truncatum Ehrenberg 1832 & & & & + \\
\hline Hannaea sp. & & + & & \\
\hline $\begin{array}{l}\text { Hannaea arcus } \\
\text { (Ehrenberg) R.M.Patrick } 1966\end{array}$ & + & & & \\
\hline Meridion circulare (Greville) C.Agardh 1831 & & + & + & + \\
\hline Navicula sp. & + & + & + & + \\
\hline $\begin{array}{l}\text { Hippodonta capitata (Ehrenberg) Lange- } \\
\text { Bertalot, Metzeltin \& Witkowski } 1996\end{array}$ & + & + & + & + \\
\hline Navicula cryptocephala Kützing 1844 & & & + & + \\
\hline Navicula lanceolata Ehrenberg 1838 & & & + & \\
\hline Navicula tripunctata (O.F.Müller) Bory 1822 & + & & & + \\
\hline Navicula viridula (Kützing) Ehrenberg 1836 & + & + & & \\
\hline Neidium affine (Ehrenberg) Pfitzer 1871 & & + & & + \\
\hline Nitzschia sp. & + & + & + & + \\
\hline Nitzschia denticula Grunow 1880 & & & & + \\
\hline Nitzschia palea (Kützing) W.Smith 1856 & + & + & & \\
\hline Nitzschia recta Hantzsch ex Rabenhorst 1862 & + & & & + \\
\hline Nitzschia sigmoidea (Nitzsch) W.Smith 1853 & & & & + \\
\hline Pinnularia sp. & & & + & + \\
\hline Pinnularia viridis (Nitzsch) Ehrenberg 1843 & & & & + \\
\hline Rhoicosphenia curvata (Kützing) Grunow 1860 & & & + & \\
\hline $\begin{array}{l}\text { Surirella brebissonii Krammer and Lange-Bert. } \\
1987\end{array}$ & + & & & \\
\hline Tabellaria flocculosa (Roth) Kützing 1844 & & + & & \\
\hline
\end{tabular}


Table 2. Continued.

\begin{tabular}{|c|c|c|c|c|}
\hline & C. mancus & C. defectus & P. scalaenum & T. kraatzi \\
\hline \multicolumn{5}{|l|}{ Kingdom: Plantae } \\
\hline \multicolumn{5}{|l|}{ Phylum: Chlorophyta } \\
\hline \multicolumn{5}{|l|}{ Class: Chlorophyceae } \\
\hline Tetraëdron minimum (A.Braun) Hansgirg 1889 & & & + & \\
\hline $\begin{array}{l}\text { Desmodesmus opoliensis (P.G.Richter) } \\
\text { E.Hegewald } 2000\end{array}$ & & & + & \\
\hline $\begin{array}{l}\text { Tetradesmus dimorphus (Turpin) M.J.Wynne } \\
2016\end{array}$ & & + & & \\
\hline $\begin{array}{l}\text { Tetradesmus lagerheimii } \\
\text { M.J.Wynne \& Guiry } 2016\end{array}$ & + & & & \\
\hline $\begin{array}{l}\text { Desmodesmus intermedius (Chodat) } \\
\text { E.Hegewald } 2000\end{array}$ & + & & & \\
\hline $\begin{array}{l}\text { Scenedesmus quadricauda (Turpin) Brébisson } \\
\text { in Brébisson \& Godey } 1835\end{array}$ & & & + & \\
\hline Kirchneriella lunaris (Kirchner) Möbius 1894 & + & & & \\
\hline Chlamydomonas sp. & + & & & \\
\hline \multicolumn{5}{|l|}{ Class: Trebouxiophyceae } \\
\hline Oocystis sp. & & & & + \\
\hline \multicolumn{5}{|l|}{ Phylum: Charophyta } \\
\hline \multicolumn{5}{|l|}{ Class: Zygnematophyceae } \\
\hline Closterium littorale F.Gay 1884 & & & & + \\
\hline $\begin{array}{l}\text { Closterium lunula Ehrenberg \& Hemprich ex } \\
\text { Ralfs } 1848\end{array}$ & & & & + \\
\hline Closterium sp. & & & & + \\
\hline Cosmarium sp. & & & & + \\
\hline Spirogyra sp. & & & & + \\
\hline \multicolumn{5}{|l|}{ Class: Ulvophyceae } \\
\hline Cladophora glomerata (Linnaeus) Kützing 1843 & & & & + \\
\hline Cladophora sp. & + & & + & + \\
\hline \multicolumn{5}{|l|}{ Kingdom: Protozoa } \\
\hline \multicolumn{5}{|l|}{ Phylum: Euglenozoa } \\
\hline \multicolumn{5}{|l|}{ Class: Euglenophyceae } \\
\hline $\begin{array}{l}\text { Trachelomonas volvocina (Ehrenberg) } \\
\text { Ehrenberg } 1834\end{array}$ & & & & + \\
\hline \multicolumn{5}{|l|}{ Kingdom: Eubacteria } \\
\hline \multicolumn{5}{|l|}{ Phylum: Cyanobacteria } \\
\hline \multicolumn{5}{|l|}{ Class: Cyanophyceae } \\
\hline Anabaena sp. & + & & & \\
\hline Chroococcus sp. & & + & & \\
\hline $\begin{array}{l}\text { Chroococcus minimus (Keissler) Lemmermann } \\
1904\end{array}$ & + & & & \\
\hline $\begin{array}{l}\text { Kamptonema formosum (Bory de Saint-Vincent } \\
\text { ex Gomont, 1892) Strunecky et al., } 2014\end{array}$ & & + & & \\
\hline $\begin{array}{l}\text { Leptolyngbya boryana (Gomont) Anagnostidis } \\
\text { \& Komárek } 1988\end{array}$ & & + & & \\
\hline Lyngbya majuscula Harvey ex Gomont 1892 & & & + & \\
\hline Oscillatoria princeps Vaucher ex Gomont 1892 & + & + & + & \\
\hline Plant Fragments & + & + & + & + \\
\hline
\end{tabular}


Table 2. Continued.

\begin{tabular}{l|cccc}
\hline & C. mancus & C. defectus & P. scalaenum & T. kraatzi \\
\hline Animal Fragments & + & + & + & + \\
\hline Fungi Spores & + & + & + & + \\
\hline Fungi Hyphal & & + & + & + \\
\hline Pollen & + & + & + \\
\hline Protozoan & + & & + \\
\hline
\end{tabular}

According to the Shannon-Wiener index results, $P$. scalaenum has the richest diversity $\left(\mathrm{H}^{\prime}=1.345\right)$ followed by $C$. defectus $\left(\mathrm{H}^{\prime}=1.303\right), C$. mancus $\left(\mathrm{H}^{\prime}=1.063\right)$, and T. kraatzi $\left(\mathrm{H}^{\prime}=0.834\right)$ (Figure 5). According to the Bray-Curtis similarity index, while the most similar types of gut contents were $P$. scalaenum and C. defectus (38\%), T. kraatzi had different gut content from the other species (Figure 6). These results were supported by Correspondence analysis (Figure 7).

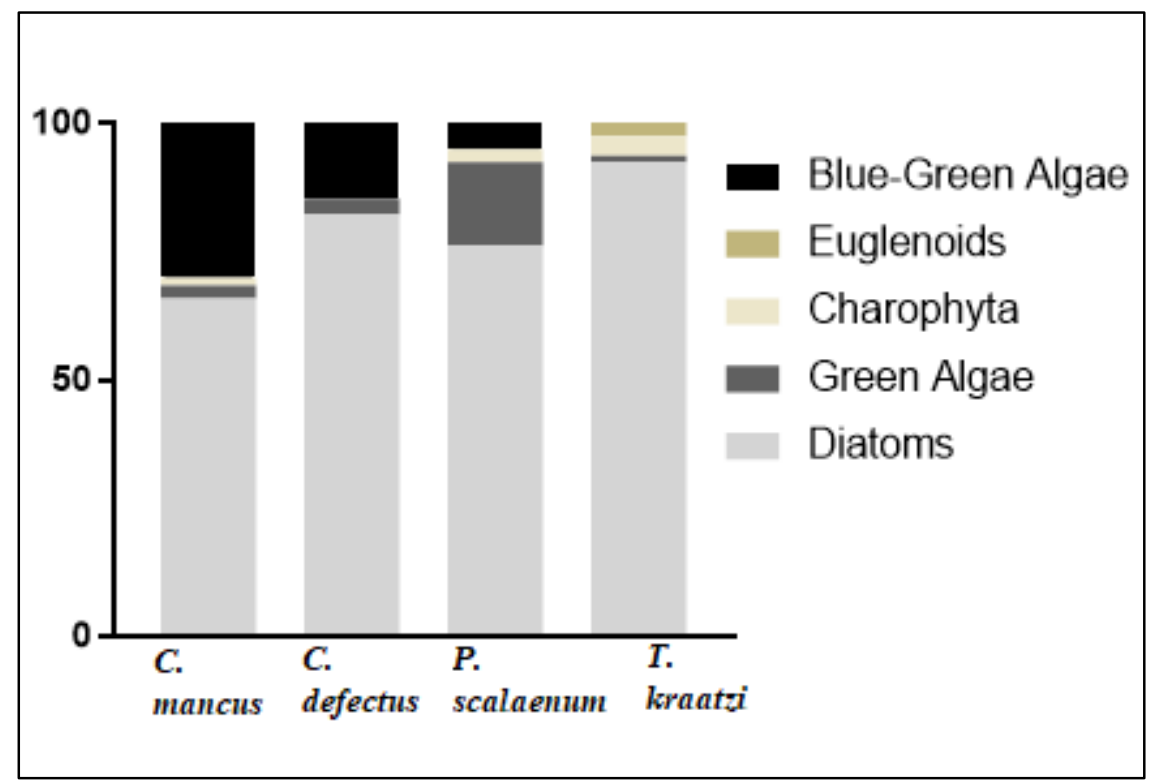

Figure 4. The algal composition of the gut contents of the determined chironomid larvae.

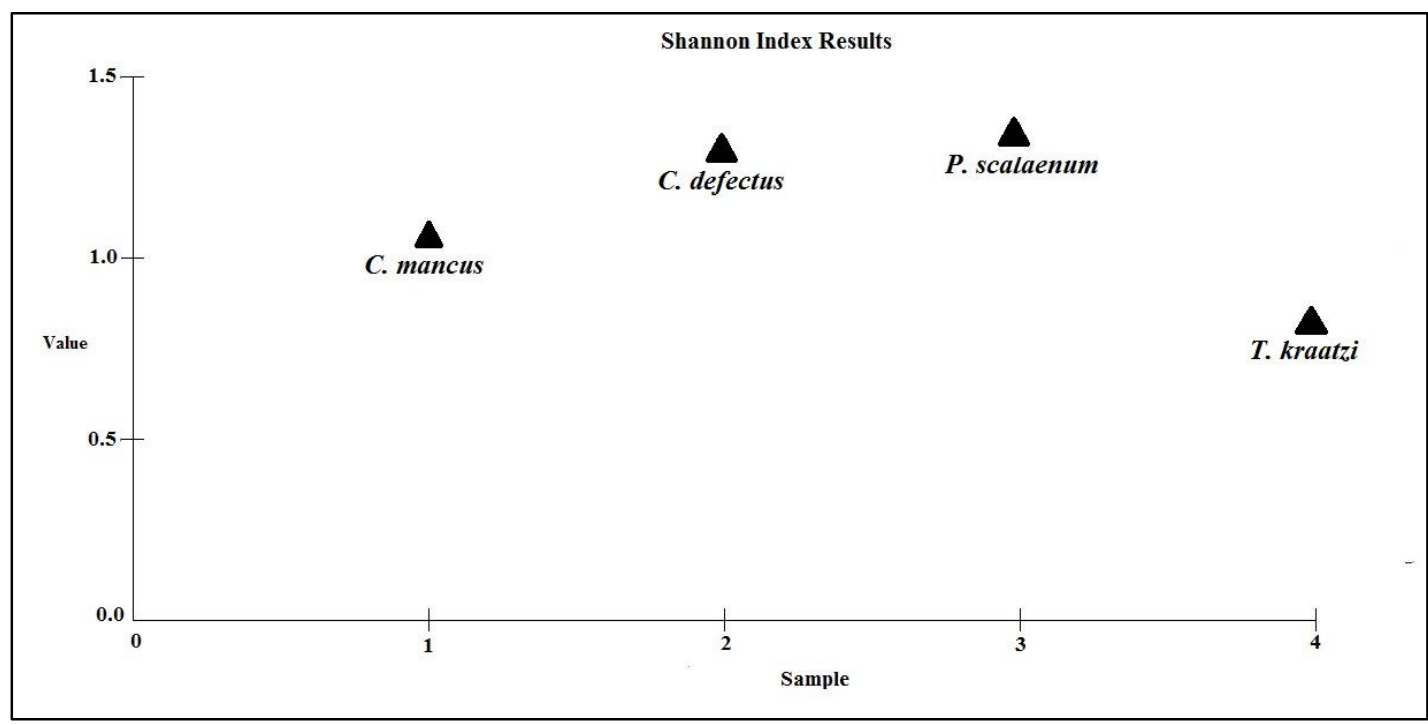

Figure 5. Species diversity (values of the Shannon-Wiener Diversity Index) of gut contents of the chironomid larvae. 


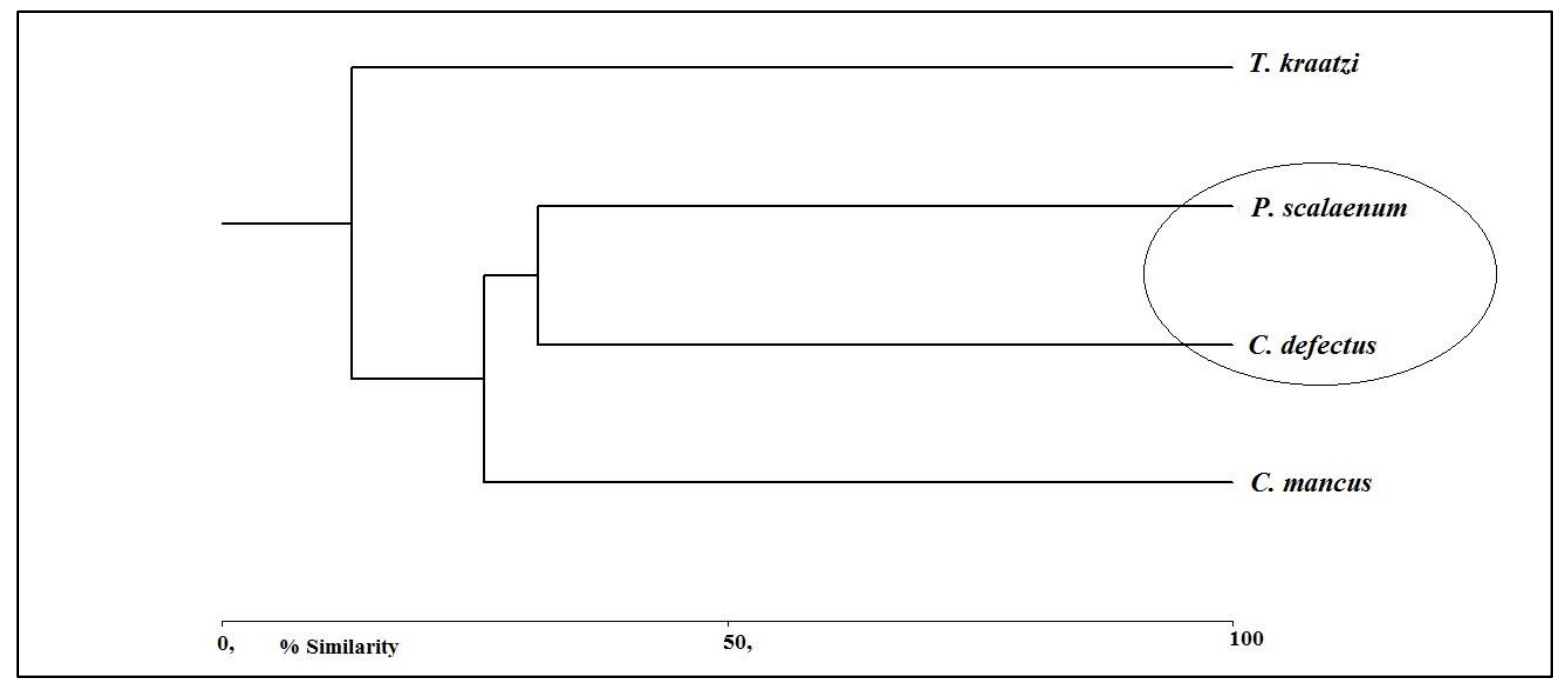

Figure 6. The gut contents similarity (based on the Bray-Curtis Similarity Index) of the chironomid larvae.

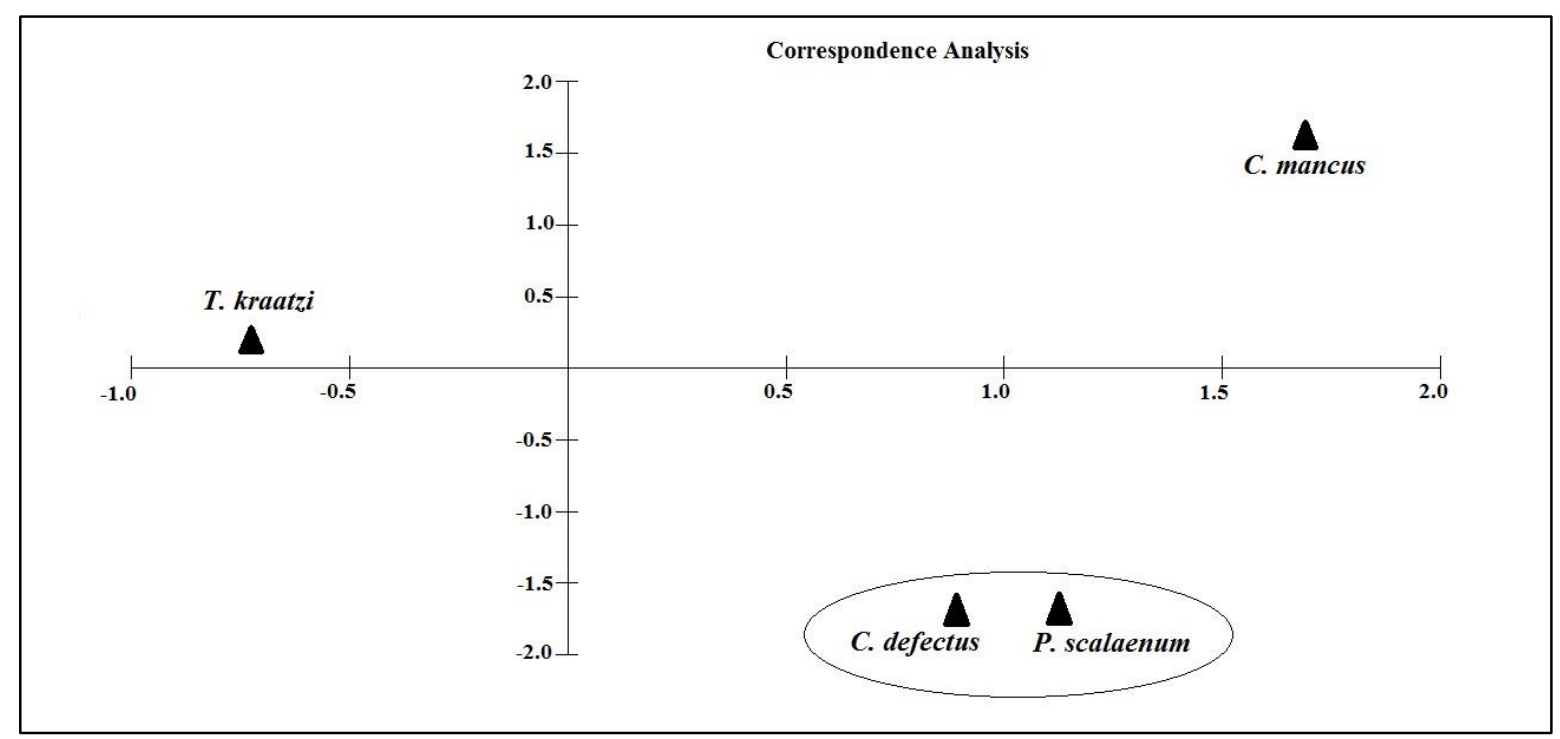

Figure 7. Correspondence analysis of the gut contents of the chironomid larvae.

\section{Discussion}

In this study, it was compared to the gut content of $C$. defectus, $C$. mancus, $P$. scalaenum, and T. kraatzi collected from the freshwater ecosystems in the Northern Thrace Region of Turkey. The main food component of the alimentary tract of Chironomidae larvae is detritus (Berg 1995; Dukowska et al. 1999; Kornijo'w et al. 2019). But in our study, the data included gut content data other than detritus. As a result of our gut content study, Algae was the dominant component as in other studies (Tarkowska-Kukuryk 2013; Butakka et al. 2016; Kornijo'w et al. 2019). According to Kornijo'w et al. (2019) food of animal origin is a less involved component than plant fragment as in our study. According to the algal composition of the gut contents of the determined chironomid species, diatoms were dominant as in the many other studies (Cattaneo 1983; Tokeshi 1986; Tarkowska-Kukuryk 2013). Although Tanypus genus is known as a predator, members of Tanypus genus can preference diatoms as a major food source (Armitage et al. 1995; Galizzi et al. 2012) and is probably the result of larval size, food size, and quality, sediment composition (Armitage et al. 1995). Also, diatoms are rich in protein and essential fatty acids and this situation makes them preferred and high-quality food for growing larvae (Tarkowska-Kukuryk 2013).

According to the Bray-Curtis similarity index results, the most similar types of gut contents were $P$. scalaenum and $C$. defectus. It could say that T. kraatzi had different gut content among the other three species. The members of the subfamily Tanypodinae (including T. kraatzi) generally feed on other organisms as predators and so the results made thought us that the food spectrum of $C$. defectus, $C$. mancus, and $P$. scalaenum (subfamily Chironominae) was broader than T. kraatzi.

Gut content studies result in attention to the importance of chironomid larvae and their energy 
flow role in aquatic ecosystems. Gut content studies provide important insights into the trophic level and food sources of aquatic ecosystems. It is known that many chironomids are grazer on epiphytes and macrophytes and because of the high abundance of chironomids the plant food sources of an aquatic ecosystem could reduce. Thanks to the gut content studies it will be possible to know where it must suppress chironomid populations. We think that the studies examining the gut content of chironomid larvae could provide a good data set to speculate on the structure of an aquatic ecosystem.

\section{References}

Addinsoft. 2015. XLSTAT, Data analysis and statistics with MS Excel. Addinsoft, NY, USA. Available from http:// www.xlstat.com/en/home

Armitage P, Cranston PS, Pinder L. 1995. The Chironomidae: Biology and ecology of non-biting midges. London, UK: Chapman and Hall 572 p.

Baker AS, McLachlan AJ. 1979. Food preferences of Tanypodinae larvae (Diptera: Chironomidae). Hydrobiologia. 62:283-288. doi:10.1007/BF00043546

Berg MB. 1995. Larval food and feeding behaviour. In: Armitage PD, Cranston PS, Pinder LCV, editors. The Chironomidae. Dordrecht: Springer. p. 136-168. doi:10.1007/978-94-011-0715-0_7

Butakka CMM, Ragonhab FH, Trainb S, Pinhab GD, Takedab AM. 2016. Chironomidae feeding habits in different habitats from a Neotropical floodplain: exploring patterns in aquatic food webs. Braz $\mathbf{J}$ Biol. 76(1):117-125. doi:10.1590/1519-6984.14614

Cattaneo A. 1983. Grazing on epiphytes. Limnol Oceanogr. 28(1):124-132

Dukowska M, Grzybkowska M, Sitkowska M, ZelaznaWiec-zorek J, Szela,g-Wasilewska E. 1999. Food resource partitioning between chironomid species connected with submerged vegetation in the River Warta below the dam reservoir, Poland. Acta Hydrobiol. 41(Suppl 6):219-229.

Epler JH. 2001. Identification manual for the larval Chironomidae (Diptera) of North and South Carolina. USA: Crawfordville $53 \mathrm{p}$.

Fittkau EJ, Roback SS. 1983. The larvae of Tanypodinae (Diptera: Chironomidae) of the Holarctic Region Keys and diagnoses. In Wiederholm $\mathrm{T}$, editor. Chironomidae of the holarctic region: keys and diagnoses. Vol 1. Larvae. Entomol Scand Suppl. 19:33-110.

Galizzi MC, Zilli F, Marchese M. 2012. Diet and functional feeding groups of Chironomidae (Diptera) in the Middle Paraná River floodplain (Argentina). Iheringia Ser Zool. 102(2):117-121. doi:10.1590/S0073-47212012000200001

Guiry MD, Guiry GM. 2020. AlgaeBase. World-wide electronic publication, National University of Ireland, Galway. [cited 2020 May 20]. Available from http://www.algaebase.org.
Hillebrand H, Dürselen C, Kirschtel D, Pollingher U, Zohary T. 1999. Biovolume calculation for pelagic and benthic microalgae. J Phycol. 35(2):403-424. doi:10.1046/j.1529-8817.1999.3520403.x

Hindak F. 2008. Colour atlas of Cyanophytes. Bratislava, Slovakia: VEDA, Publishing House of the Slovak Academy of Sciences $253 \mathrm{p}$.

Huber-Pestalozzi G. 1982. Das phytoplankton des Süßwasser Teil: 8 E. Stuttgart: Schweizerbart'sche Verlagsbuchhandlund (N ägele U. Obermiller).

John DM, Whitton BA, Brook, JA. 2002. The freshwater algal flora of British Isles, An identification guide to freshwater and terrestrial algae. Cambridge: Cambridge University Press 702 p,

Komárek J, Anagnostidis K. 2005. Cyanoprokariota. 2. Teil: Oscillatoriales. In: Büdel B, Gärtner G, Krienitz L, Schagerl M, editors. Süßwasserflora von Mitteleuropa. Heidelberg: Elsevier.

Kornijo'w R, Markiyanova M, Lange E. 2019. Feeding by two closely related species of Chironomus (Diptera: Chironomidae) in south Baltic lagoons, with implications for competitive interactions and resource partitioning. Aquat Ecol. 53(3):315-324. doi: 10.1007/s 10452-019-09691-7

Krammer K, Lange-Bertalot H. 1986-2004. Bacillariophyceae. 1-4 Teil. Süsswasserflora von Mitteleuropa. H Ettl, J Gerloff, H Heynig, and D Mollenhauer, editors. Germany: Springer Spektrum.

Kristiansen J, Preisig HR. 2011. Phylum chrysophyta (Golden Algae). In: John DM, Whitton BA, Brook AJ, editors. The freshwater algal flora of the British Isles. An identification guide to freshwater and terrestrial algae. Second edition. Cambridge: Cambridge University Press. p. 281-310.

Manko P. 2016. Stomach content analysis in freshwater fish feeding ecology. Vydavatel'stvo Prešovskej Univerzity, ISBN 978-80-555-1613-4. [cited 2020 March 20]. Available from https://www.unipo.sk/public/media/30699/2016_PV_ MANKO_Stomach_content_fish.pdf

Öterler B, Aydın GB, Çamur-Elipek B. 2018. Qualitative and quantitative examination of algal flora in the gut content of Tanypus punctipennis Meigen, 1818. Süleyman Demirel University Journal of Natural and Applied Sciences. 22(1):88-94. doi:10.19113/sdufbed.45882

Pinder LCV, Reiss F. 1983. The larvae of chironominae (diptera: chironomidae) of the holarctic region - keys and diagnoses. In Wiederholm $\mathrm{T}$, editor. Chironomidae of the holarctic region: keys and diagnoses. Vol 1. Larvae. Entomol ScandSuppl. 19:149-294.

Rodina AG. 1971. The role of bacteria in feeding of the tendipedid larvae. Fisheries Research Board of Canada Translation Series No.1848.

Round FE, Crawford RM, Mann DG. 1990. The diatoms, biology \& morphology of the genera. Cambridge: Cambridge University Press 747 p.

Saether OA. 1980. Glossary of chironomid morphology terminology (Diptera: Chironomidae). Entomol Scand Suppl. 14:1-51. 
Sanseverino AM, Nessimian JL. 2008. The food of larval Chironomidae (Insecta, Diptera) in submerged litter in a forest stream of the Atlantic Forest (Rio de Janeiro, Brazil). Acta Limnol Bras. 20(1):15-20.

Silva FL, Ruiz SS, Bochini GL, Moreira DC. 2008. Functional feeding habits of Chironomidae larvae (Insecta, Dipotera) in a lotic system from Midwestern Region of Sao Paulo State, Brazil. Panamjas, 3(2):135-141.

Sun J, Liu D. 2003. Geometric models for calculating cell biovolume and surface area for phytoplankton. J Plankton Res. 25(11):1331-1346.

doi:10.1093/plankt/fbg096
Tarkowska-Kukuryk M. 2013. Periphytic algae as food source for grazing chironomids in a shallow phytoplankton-dominated lake. Limnologica. 43(2013):254-264.

doi: 10.1016/j.limno.2012.11.004

Tokeshi M. 1986. Resource utilization overlap and temporal community dynamics: a null model analysis of an epiphytic chironomids community. J Anim Ecol. 55(2):491-506. doi:org/10.2307/4733

Vallenduuk JH, Morozova E. 2005. Cryptochironomus, an identification key to the larvae and pupal exuviae in Europe. Lauterbornia. 55:1-22. 